\title{
Study of precipitation reactions to Actinomyces israelii antigens in uterine secretions
}

\author{
ELISABETH PERSSON, ${ }^{*}$ KENNETH HOLMBERG $\dagger$
}

From the ${ }^{*}$ Department of Obstetrics and Gynaecology, Karolinska Institutet, Danderyd Hospital, and the †Section for Medical Mycology, National Bacteriological Laboratory, Stockholm, Sweden

SUMMARY Uterine secretions were obtained from 110 women and analysed by counterimmunoelectrophoresis for the occurrence of precipitation reactions against Actinomyces israelii antigens. Precipitation reactions were found in secretions from seven women and a correlation was found between these reactions and long term use of plastic intrauterine devices. The precipitating components could not be proved to be immunoglobulins; neither could identity be shown with IgG precipitins in reference serum. The nature and the importance of the precipitating components are discussed.

Actinomyces israelii, the predominant pathogen of human actinomycosis, has recently been identified as a part of the indigenous genital flora. ${ }^{-3}$ Actinomycotic involvement of the female pelvis is often associated with long term use of intrauterine contraceptive devices (IUCDs) ${ }^{4}$ Prevalence studies have, however, failed to show an increase in colonisation rate with duration of IUCD use. ${ }^{5}$ An association with IUCD use and the occurrence of Actinomyces like organisms in Papanicolaou stained cervicovaginal smears was first documented by Gupta et al in 1976..$^{\circ}$ The importance of the identification of Actinomyces like organisms in cervicovaginal smears is not clear; nor are the conditions for their formation. Factors other than the mere existence of Actinomyces in the genital tracts of women with IUCDs must be important for disease development. Specific antibodies against $A$ israelii have been detected in serum from patients with genital actinomycosis. ${ }^{78}$ In an attempt to study the possibility of detecting a local antibody response to $A$ israelii in uterine secretions the following study was performed.

\section{Material and methods}

SUBJECTS

A group of women participating in a study of the effects of long term use of IUCDs, which will be presented elsewhere (Persson $e t$ al, in preparation),

Accepted for publication 19 September 1984 were examined. As reference, a number of women without IUCDs and with IUCDs for less than three years, including women with Actinomyces like organisms detected in routine cervical smears, were examined. The women were subdivided into groups as follows.

Group 1: seven asymptomatic women using barrier methods of contraception.

Group 2: 78 women using copper IUCDs. Eleven women had used the IUCDs for two to three years and four of them were included because they had Actinomyces like organisms detected in routine cervical smears. The remaining 67 women had been fitted with the same copper IUCD for six to eight years. Results of analysis of cervical smears were not available from these women.

Group 3: 25 women who had had plastic IUCDs for more than six years (Table).

None of the IUCD users had symptoms or signs of genital infections. From two women repeated samples were obtained after two and 12 months.

\section{SAMPLING PROCEDURES \\ Uterine secretions}

Uterine secretions were obtained for analysis from all women examined. The cervix was wiped with a chlorohexidine solution and a sterile plastic catheter attached to a syringe was introduced into the uterine cavity. A slight suction was applied with the syringe to fill the catheter with uterine secretions. After extraction, the mucus filled part of the catheter was cut off and put into a box with a damp cotton swab to avoid drying of the sample. 
Different contraceptive methods used by women examined related to results of analyses of uterine and cervical secretions by counterimmunoelectrophoresis

\begin{tabular}{|c|c|c|c|c|}
\hline \multirow[t]{2}{*}{ Group } & \multirow[t]{2}{*}{ No of women } & \multirow[t]{2}{*}{ Contraceptive method used } & \multicolumn{2}{|c|}{$\begin{array}{l}\text { Precipitation reactions } \\
\text { detected in }\end{array}$} \\
\hline & & & $\begin{array}{l}\text { Uterine } \\
\text { secretions }\end{array}$ & $\begin{array}{l}\text { Cervical } \\
\text { secretions }\end{array}$ \\
\hline $\begin{array}{l}1 \\
2 \\
3\end{array}$ & $\begin{array}{r}7 \\
78 \\
25 \\
110\end{array}$ & $\begin{array}{l}\text { Barrier methods } \\
\text { Copper IUCDs } \\
\text { Plastic IUCDs }\end{array}$ & $\begin{array}{l}0 \\
2 \\
5 \\
7\end{array}$ & $\begin{array}{l}0 \\
1^{*} \\
\text { ND } \\
1\end{array}$ \\
\hline
\end{tabular}

*Cervical secretions obtained from 11 women.

$\mathrm{ND}=$ not done.

\section{Cervical secretions}

Cervical secretions were obtained from the women in group 1 and from the 11 women in group 2 who had had copper devices for two to three years. As much as possible of the mucus visible in the cervical os was suctioned into a catheter before obtaining uterine samples. The catheters were then handled as described above.

\section{Serum samples}

Ten millilitres of blood was drawn from each woman for serological analysis.

All sampling was performed at the time of ovulation or in the secretory phase of the menstrual cycle.

\section{LABORATORY METHODS}

\section{Counterimmunoelectrophoresis}

Counterimmunoelectrophoresis was performed in a

$1 \%$ (wt/vol) agarose solution (Litex, Glostrup, Denmark) cast as a $1 \mathrm{~mm}$ thick layer on plates made of polyester (Gel Bond). ${ }^{9}$ A 0.075 M Tris/Barbital buffer, at $\mathrm{pH} 8.6$, was used for the gels and the electrode vessels. In the primary analysis, wells holding $10 \mu \mathrm{l}$ were cut in parallel rows $1 \mathrm{~cm}$ apart. Aliquots of $10 \mu \mathrm{l}$ of $A$ israelii antigen, produced as described elsewhere ${ }^{810}$ and containing $0.005 \mu \mathrm{g}$ protein $/ \mathrm{ml}$, were placed in the wells nearest to the cathode in each row. Arbitrary amounts of secretions were cut by means of scissors, in portions suitable to fill the wells nearest to the anode. Electrophoresis was then carried out at $10 \mathrm{~V}$ per $\mathrm{cm}$ at $10-12^{\circ} \mathrm{C}$ for $30 \mathrm{~min}$ in an apparatus suitable for the purpose (Medelco, Bromma, Sweden). After a wash in physiological saline the plates were stained in a solution of $0.5 \%(\mathrm{wt} / \mathrm{vol})$ Coomassie brilliant blue $\mathrm{R}-250$ in ethanol, acetic acid, and water $(40 / 10 / 50)$ and destained in the same solution without Coomassie brilliant blue. They were then examined for precipitin lines.

A second analysis, according to Moody," "was performed to compare the identities of precipitates with those obtained when using a defined reference serum. The sample of secretions was put in a well close to one with reference antiserum, both close to the anode. The antigen was placed in a well opposite these and closer to the cathode. Electrophoresis was then performed as described above.

Serum analyses for the detection of precipitating antibodies were performed using counterimmunoelectrophoresis as described above but with $A$ israelii antigen containing $0 \cdot 2 \mu \mathrm{g}$ protein $/ \mathrm{ml}$.

\section{Rocket immunoelectrophoresis}

Rocket immunoelectrophoresis was performed as described elsewhere. ${ }^{12}$ A $1 \%$ (wt/vol) agarose solution (Litex, Glostrup, Denmark) dissolved in a Tris/Barbital buffer, pH 8.6, was mixed with rabbit antihuman immunoglobulins (A 107, Dakopatts, Copenhagen, Denmark) and cast to form a $1 \mathrm{~mm}$ thick gel on polyester plates (Gel Bond) measuring $10 \times 10 \mathrm{~cm}$. The antiserum was added in amounts of $4 \mu \mathrm{l} / \mathrm{cm}^{2}$. Wells holding $5 \mu \mathrm{l}$ were cut in a row nearest to the cathode. Standards of immunoglobulins with protein contents of $16 \mathrm{mg} / \mathrm{ml}, 8 \mathrm{mg} / \mathrm{ml}$, and 4 $\mathrm{mg} / \mathrm{ml}$ were used. These and the test samples were carbamylated before testing by incubation for 30 min at $45^{\circ} \mathrm{C}$ after mixing with a $\mathrm{KOCN}$ solution in borate buffer. ${ }^{13}$ The samples were then applied and electrophoresis was performed at 1-2 $\mathrm{V}$ per $\mathrm{cm}$ at $10-12^{\circ} \mathrm{C}$ overnight. The gels were washed and stained as described above. The immunoglobulin concentration of the test samples was determined by interpolation on the standard curve obtained.

\section{Crossed immunoelectrophoresis}

Crossed immunoelectrophoresis with an intermediate gel was performed as described by Axelsen. ${ }^{14}$

\section{Direct microscopy and cultures}

Smears for direct microscopy were prepared from the secretions and inoculations for anaerobic culture were made on supplemented brain heart infusion and on gelatin metronidazole cadmium sulphate agar media. The smears were examined by Gram 
staining and by the use of immunofluorescent techniques. Further proceedings were the same as described elsewhere. ${ }^{21516}$

\section{Assay design}

All specimens were taken to the laboratory within $24 \mathrm{~h}$. Specimens for cultures and direct microscopy were prepared immediately after the arrival of the samples in the laboratory. The secretions were then transferred into tubes, frozen, and stored at $-20^{\circ} \mathrm{C}$. All immunological analyses of the secretions were made simultaneously after thawing. All sera were analysed by counterimmunoelectrophoresis and when the precipitins persisted in more than a fourfold dilution further analysis by crossed immunoelectrophoresis was performed to determine whether or not the precipitins were specific against $A$ israelii. ${ }^{78} 10$

\section{Results}

Distinct precipitation reactions were detected by counterimmunoelectrophoresis in secretions from seven of the 110 women examined (Table). Uterine samples from three of these women were contaminated with blood, but in none of them were any precipitins detected in serum. The immunoglobulin content of six of the positive secretions was determined by rocket immunoelectrophoresis. Immunoglobulins were detected in all samples tested, with concentrations of $4 \mathrm{mg} / \mathrm{ml}$ or less. The exact concentration was not determined as the amount of sample applied was arbitrary because of the physicochemical properties of the secretions. A second counterimmunoelectrophoresis analysis was performed with the positive secretions to check the identity with a reference antiserum against $A$ israelii. In none of the secretion samples was identity demonstrated with the defined precipitins in the reference serum.

Nineteen women had precipitins detected in serum by counterimmunoelectrophoresis. Eight of these persisted in a fourfold serum dilution but were defined as non-specific by crossed immunoelectrophoresis. None of these women had precipitation reactions in secretion analyses.

One woman with precipitation reactions in her secretions had had a copper IUCD for two years. The reactions were detected both in cervical and uterine secretions. She had Actinomyces like organisms in Papanicolaou stained cervical smears but was asymptomatic. Her IUCD was removed. Reexamination two months later showed no Actinomyces like organisms in cervical smears, no $A$ israelii, and no precipitation reactions in her secretions. Of the remaining six women with precipita- tions one had had a copper device for six years while five had had plastic devices for more than nine years. In one of the latter $\boldsymbol{A}$ israelii was identified in uterine secretions. Repeat samples were obtained from her one year later with the same results. She was still asymptomatic.

A significant difference was found $(p<0.02)^{17}$ in the occurrence of precipitation reactions when plastic IUCD users were compared with women with copper devices. The plastic IUCDs had been used for 9-17 years while the copper devices had been fitted for six years or less. The significance remains the same if the material is stratified for duration of IUCD use instead of type of IUCD.

\section{Discussion}

Precipitation reactions with $A$ israelii antigens were found in uterine secretions from seven women. Serum precipitins against the organisms were not found in any of these women. This indicates local production of the precipitating components. The presence of antibodies in genital secretions has been documented by many authors. ${ }^{18-27}$ The major portion of the IgG has been attributed to transudation from serum. Secretory IgA and part of the IgG present in secretions have been shown by means of fluorescent antibody techniques to be produced by submucosal plasma cells residing locally in the endocervix and the endometrium. ${ }^{26}$ When inflammation occurs in the mucous membranes both an increase in transudation of $\mathrm{IgG}$ from serum and an invasion of immunoglobulin producing plasma cells have been found. In the present study the precipitating components could not be shown to be immunoglobulins. In six positive cases, however, the presence of antibodies in secretions was proved but we were unable to determine the immunoglobulin class. The precipitins against $A$ israelii in serum have by adsorption studies, been shown to be of the IgG class (unpublished data). Identity between the precipitating compounds in secretions and the precipitins in $A$ israelii reference antiserum could not be shown. This might be explained by the precipitating components being antibodies of the secretory $\operatorname{IgA}$ class and thereby failing to show identity with the IgG precipitins in the reference serum. In a pilot study, attempts were made to extract antibodies from the secretions with physiological buffer followed by centrifugation. No precipitation reactions were shown with the extracts. Reactions were, however, found when assaying the whole body of the same secretions, as described above. A number of components in the mucus-for example, lysozyme-might cause precipitations in the assays used and the precipitation reactions detected might 
be due to non-specific non-antigen-antibody reactions. ${ }^{24} 28$

Precipitation reactions in secretions were detected significantly more often in women with plastic IUCDs than in women with copper devices. All plastic IUCDs of the women with precipitation reactions had been used for long periods of time. This is concordant with the disease of genital actinomycosis occurring mainly in women after long term IUCD use. ${ }^{4}$ Duguid et al ${ }^{29}$ found Actinomyces like organisms more often in women with plastic IUCDs than in women with copper devices. We can only speculate as to whether the precipitation reactions found in these assays are important for the formation of Actinomyces like organisms. The exact nature of the reacting components and their importance for $A$ israelii colonisation and in disease development needs to be further investigated.

We are grateful to Dr Olle Frankman, Södersjukhuset, Stockholm, for submitting samples from long term IUCD users.

This study was made possible by economic support from Organon AB and from Torsten and Ragnar Söderbergs Foundations.

\section{References}

' Persson E, Holmberg K, Dahlgren S, Nilsson L. Actinomyces israelii in the genital tract of women with and without intrauterine contraceptive devices. Acta Obstet Gynecol Scand 1983;62:563-8.

${ }^{2}$ Persson E, Holmberg K. A longitudinal study of Actinomyces israelii in the female genital tract. Acta Obstet Gynecol Scand 1984;63:207-16.

${ }^{3}$ Pine L, Bradley Malcolm G, Curtis EM, Brown JM. Demonstration of Actinomyces and Arachnia species in cervico-vaginal smears by direct staining with species-specific fluorescentantibody conjugate. J Clin Microbiol 1981;13:15-21.

${ }^{4}$ Schmidt WA, Bedrossian CMW, Ali V, Webb JA, Bastian FO. Actinomycosis and intrauterine contraceptive devices. The clinicopathologic entity. Diagn Gynecol Obstet 1980;2:16577.

s Persson E, Holmberg K. Genital colonization by Actinomyces israelii and serologic immune response to the bacterium after five years use of the same copper intra-uterine device. Acta Obstet Gynecol Scand 1984;63:203-5.

- Gupta PK, Hollander DH, Frost JK. Actinomycetes in cervicovaginal smears: An association with IUD usage. Acta Cytol 1976;20:295-7.

' Holmberg K. Immunodiagnosis of human actinomycosis. In: Pulverer G, Schaal KP, eds. Actinomycetes. Zbl Bakt Suppl 11. New York: Gustav Fischer Verlag, 1981:259-61.

${ }^{8}$ Persson E, Holmberg K. Clinical evaluation of precipitin tests for genital actinomycosis. J Clin Microbiol (in press).

${ }^{9}$ Edwards EA. Counterimmunoelectrophoresis and double immunodiffusion. In: Rytel MW, ed. Rapid diagnosis in infectious disease. Florida: CRC press, 1979:19-38.
${ }^{10}$ Holmberg K, Nord C-E, Wadstrom T. Serological studies of Actinomyces israelii by crossed immunoelectrophoresis: Standard antigen-antibody system for $A$ israelii. Infect Immun 1975; 12:387-97.

"Moody GJ. Methodology and applications of countercurrentimmunoelectrophoresis in microbiology. Laboratory Practice 1976; I: 575-80.

${ }^{12}$ Axelsen NH, Bock E. Electroimmunoassay (Rocket immunoelectrophoresis). Scand J Immunol 1983;17: suppl 10:103-6.

${ }^{13}$ Bjerrum OJ, Løwenstein H. Immunoelectrophoresis utilizing carbamylated antibodies. Scand J Immunol 1983;17: suppl 10:225-32.

14 Axelsen NH. Intermediate gel immunoelectrophoresis. Scand J Immunol 1983;17: suppl 10:141-9.

is Holmberg K, Forsum U. Identification of Actinomyces, Arachnia, Bacterionema, Rothia and Propionibacterium species by defined immunofluorescence. Appl Microbiol 1973;25:834 43.

${ }^{16}$ Holmberg K, Nord C-E. Numerical taxonomy and laboratory identification of Actinomyces and Arachnia and some related bacteria. J Gen Microbiol 1975;91:17-44.

${ }^{17}$ Lindgren BW. Statistical theory. 2nd ed. Toronto: Macmillan Company, 1968.

${ }^{18}$ Behrman SJ, Lieberman ME. Biosynthesis of immunoglobulins by the human cervix. In Blandau RJ, Moghisse $\mathrm{K}$, eds. The biology of the cervix. Chicago: The University of Chicago Press, 1973:235-50.

${ }^{14}$ Chipperfield EJ, Evans BA. The influence of local infection on immunoglobulin formation in the human endocervix. Clin Exp Immunol 1972;11:219-23.

${ }^{20}$ Jalanti $\mathbf{R}$, Isliker $\mathbf{H}$. Immunoglobulins in human cervico-vaginal secretions. Int Arch Allergy Appl Immunol 1977;53:402-8.

2' Kearns DH, O' Reilly RJ, Lee L, Welch BG. Secretory IgA antibodies in the urethral exudate of men with uncomplicated urethritis due to Neisseria gonorrhoeae. J Infect Dis 1973;127:99-101.

${ }^{22} \mathrm{McNabb}$ PC, Tomasi TB. Host defence mechanisms at mucosal surfaces. Ann Rev Microbiol 1981;35:477-96.

${ }^{23}$ Rebello R, Green FHY, Fox H. A study of the secretory immune system of the female genital tract. Br J Obstet Gynaecol 1975;82:812-6.

${ }^{24}$ Schumacher GFB. Soluble proteins in cervical mucus. In: Blandau RJ, Moghissi K, eds. The biology of the cervix. Chicago: The University of Chicago Press, 1973:201-34.

${ }^{25}$ Tomasi TB, McNabb PC. The secretory immune system. In: Fudenberg HH, Stites DP, Caldwell JL, Wells JV, eds. Basic and clinical immunology. 3rd edn. Los Altos: Lange Medical Publications, 1980:240-50.

${ }^{26}$ Tourville DR, Ogra SS, Lippes J, Tomasi TB. The human female reproductive tract: Immunohistological localization of IgA, IgG, IgM, secretory "piece" and lactoferrin. Am J Obstet Gynecol 1970; 108:1102-8.

${ }^{27}$ Waner JL, Hopkin DR, Weller TH, Allred EN. Cervical excretion of cytomegalovirus: correlation with secretory and humoral antibody. J Infect Dis 1977;136:805-9.

${ }^{28}$ Wadström T. Immunoelectro-osmophoresis or counterimmunoelectrophoresis. Scand J Immunol 1983;17: suppl 10:97-102.

${ }^{24}$ Duguid HLD, Parratt D, Traynor R. Actinomyces-like organisms in cervical smears from women using intrauterine contraceptive devices. Br Med J 1980;281:534-7.

Requests for reprints to: Dr Elisabeth Persson, Department of Obstetrics and Gynaecology, Danderyd Hospital, S-182 88 Danderyd, Sweden. 